\title{
The Yucatan peninsula: biogeographical history 65 million years in the making
}

\author{
Ella Vázquez-Domínguez and Héctor T. Arita
}

E.Vázquez-Domínguez (evazquez@ecologia.unam.mx), Inst. de Ecología, Universidad Nacional Autónoma de México, Ap. Postal 70-275, Ciudad Universitaria, México DF, 04510, México. - H. T. Arita, Centro de Investigaciones en Ecosistemas, Universidad Nacional Autónoma de México, Antigua Carretera a Pátzcuaro No. 8701, Col. Ex-Hacienda de San José de La Huerta, 58190, Morelia, Michoacán, México.

The fourth biennial meeting of the International Biogeography Society (IBS) in Merida, Yucatan in January 2009 represented a double opportunity for Mexican biologists. First, it fostered the integration of the large community of Mexican biogeographers with the activities of the IBS. Second, the meeting allowed us to welcome a large number of delegates from distant parts of the world who were able to visit what has been considered an obligate destination for nature lovers and cultural tourists alike: the Yucatan peninsula.

As Edward O. Wilson pointed out, besides economic power every country has two additional and important types of wealth: cultural and natural. Cultural richness is a naturally embedded component of the Mexican way of life. It is manifested in the rich legacy of ancient Mesoamerican civilizations, in the remarkable diversity of human groups, indigenous languages and dialects, local customs and food, and also in the seamless integration of modernity with tradition that can be seen in every major city. This cultural wealth is paralleled by an amazing natural richness, best illustrated by the country's extremely high biological diversity. Mexico is the only nation in the world containing the totality of a continental border between two biogeographic realms, the Nearctic and the Neotropical. The mixing of elements of these two regions across a highly heterogeneous landscape is the perfect recipe for a "megadiverse" country like Mexico.

Mexico's cultural and natural richness becomes rapidly evident to any traveller to the Yucatan peninsula. Consider the caves of the southern part of the state of Yucatan as an example. In many of these caves, a casual visitor will notice a multitude of fossil seashells embedded in the walls and ceiling. Looking down, she could find small pieces of Maya ceramics interspersed with the sediment, and perhaps even a piece of the tooth of a Pleistocene horse Equus conversidens. These three interesting elements are in fact separated by orders of magnitude of time (Fig. 1): the limestone with the shells is of Oligocene origin, ca 25 million yr old, the horse became extinct some $10000 \mathrm{yr}$ ago, and the piece of ceramic is around $800 \mathrm{yr}$ old. Furthermore, a much larger and older piece of evidence of a past event might be in front of the visitor: many of the large sinkholes that punctuate the landscape of the Yucatan are located along the rim of the Chicxulub crater, a $180-\mathrm{km}$ wide scar created by the impact of an enormous asteroid 65 million yr ago that is believed to have caused the mass extinction event of the end of the Cretaceous. Standing in front of this diverse mixing of elements of various origins, one cannot help being amazed by the particularities of the geologic, evolutionary and cultural history of the Yucatan that have produced the present-day diversity of this unique part of Mexico.

In this introduction to the special section of papers presented at the IBS meeting, we offer a brief overview of the biological and cultural features that make the Yucatan peninsula such a special place. When choosing a Mexican venue for the IBS meeting, our first option was Merida, the "White City", the peaceful and charming capital of the state of Yucatan. What better place could it be for a biogeography meeting than atop a $180-\mathrm{km}$ wide, 65 million yr old crater that testifies one of the most spectacular events in the history of life on Earth?

\section{5 million years of history}

\section{Chicxulub: the dinosaur connection}

It can be safely stated that the biological history of the Yucatan started, or at least was reset, 65 million yr ago (Fig. 1). The Cretaceous-Tertiary (KT) episode that happened then is one of the so-called "big-five" extinction events in the history of life on Earth (Raup and Sepkoski 1982, Alroy et al. 2008). The KT episode wiped out $>75 \%$ of all animal species, including entire clades such as non-avian dinosaurs, ammonites, rudists and inoceramid bivalves (Marshall and Ward 1996). Current knowledge strongly suggests that the KT event was triggered by the collision of a $10-\mathrm{km}$ asteroid with what is now the northern Yucatan peninsula, producing a 100 million megaton explosion that in an instant obliterated the geological 


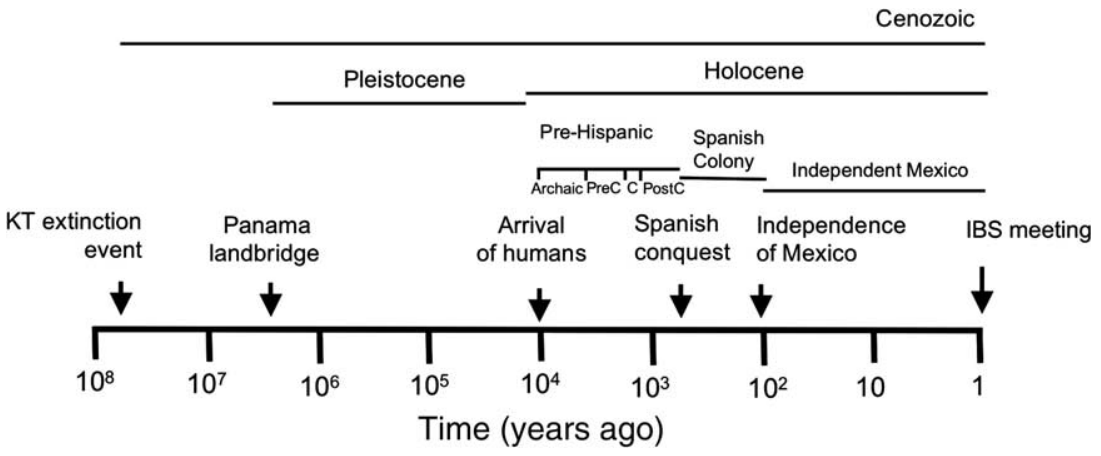

Figure 1. Time line of major events in the biogeographical history of the Yucatan peninsula. Periods of the Pre-Hispanic era are: Paleoindian, Archaic, Preclassic, Classic, and Postclassic. Note the logarithmic scale.

profile of the region and extinguished all life in hundreds of kilometres around.

When first proposed (Alvarez et al. 1980), the idea of an extraterrestrial object hitting the Earth 65 million yr ago was received with considerable scepticism. The hypothesis was supported by the strong empirical evidence of a spike in iridium concentration in sediments 65 million $\mathrm{yr}$ old, exactly at the K-T transition. Because iridium is an extremely rare element on Earth but occurs in measurable concentrations in extraterrestrial objects, the most plausible explanation for such a spike was a space object colliding with the Earth, disintegrating in an explosion that dispersed iridium-rich sediment all over the world. The Alvarez team calculated that the hypothetical asteroid or comet should have measured ca $10 \mathrm{~km}$, and should have produced a crater $200 \mathrm{~km}$ in diameter. One of the problems with the theory was that no crater of the right age and size was known at the time.

Shortly after the Alvarez et al. (1980) paper was published, Allan Hildebrand and Stein Boynton developed a theoretical model for an asteroid impact as predicted by Alvarez and collaborators, and called for a search for the missing crater. Unknown to Hildebrand and Boynton, evidence for a candidate crater fitting the theoretical description had been found in the 1960s and 1970s during oil exploration drillings financed by the Mexican oil company PEMEX. In 1981, Glen Penfield used the PEMEX data to describe an underwater crater north of Yucatan, but his report went unnoticed. Many years later, as Penfield and Hildebrand joined forces, the evidence was finally published in a scientific paper proposing an underground circular feature $180 \mathrm{~km}$ in diameter centred in the coastal town of Chicxulub as a formal candidate for the missing crater of the KT impactor (Hildebrand et al. 1991).

Today, most scientists have accepted the idea that an extraterrestrial impact caused the KT mass extinction, and that the Chicxulub crater is indeed the scar of that episode (Fig. 1, 2) (Schulte et al. 2010). Statistical analyses of the fossil record show that besides background extinction throughout most of the Cretaceous, there was a clear mass extinction of ammonites coinciding with the KT boundary (Marshall and Ward 1996). There is also physical evidence of the short- and long-term effects of the collision in areas adjacent to the peninsula and farther away: the
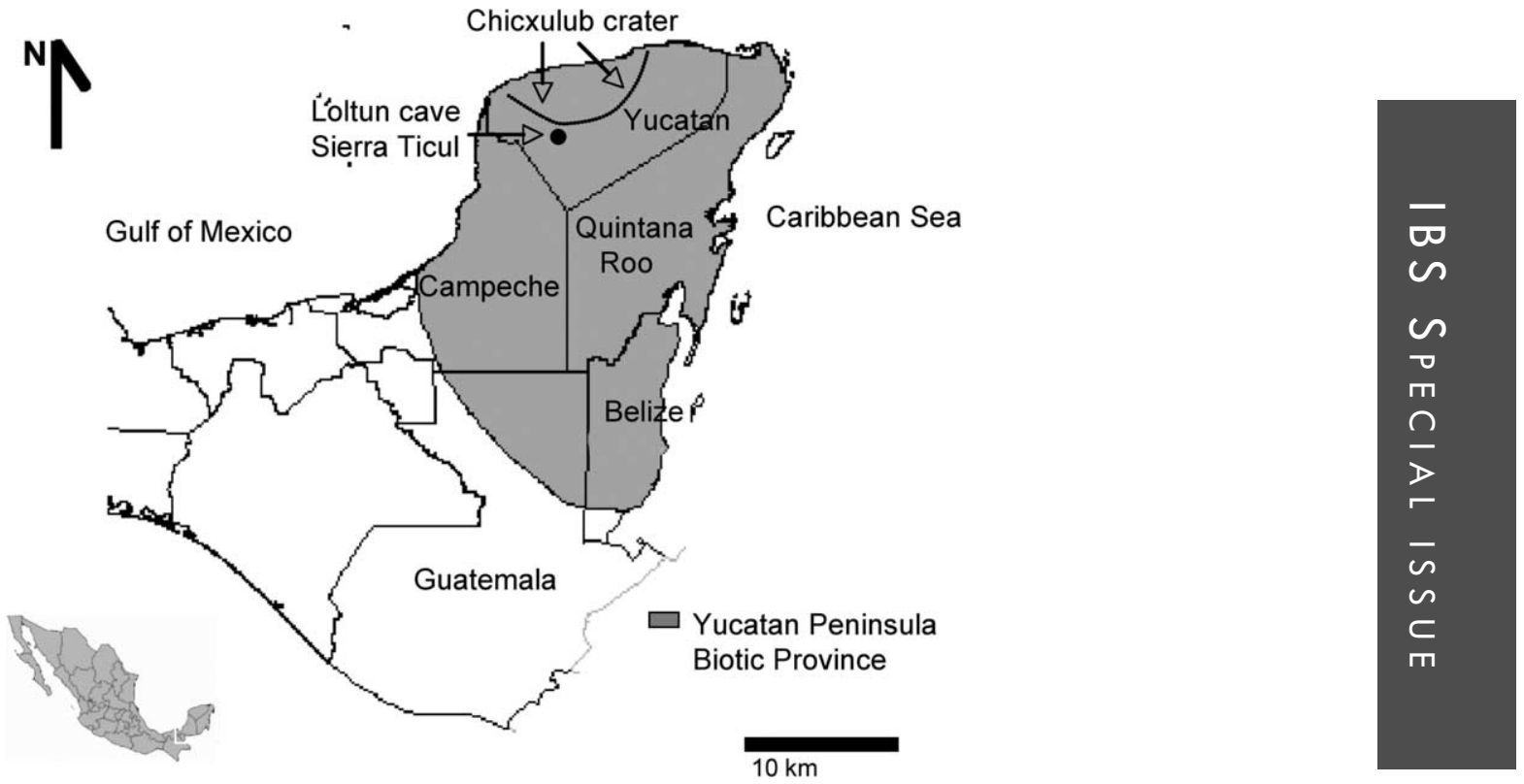

Figure 2. Yucatan peninsula (states of Yucatan, Campeche and Quintana Roo), with location of the Chicxulub crater (ring of cenotes) and Sierrita de Ticul-Loltun cave, and the limits of the Yucatan Peninsula Biotic Province. 
100-million megaton explosion, mega-tsunamis with 300$\mathrm{m}$ waves, wildfires hundreds of kilometres away from ground zero, massive forest destruction, global climate change with a subsequent reduction of $80 \%$ in the photosynthesis rate, and of course mass extinction of plant and animal species (Kring 2007). Recent analyses of material extracted from the site have dated the Chicxulub crater at 0.3 million $\mathrm{yr}$ (Myr) before the KT horizon, casting doubt on the idea that the Chicxulub object was the sole detonator of the KT extinction (Keller et al. 2004). These findings, which suggest a more complex series of events, including even multiple impacts, have ignited a new round of controversy regarding the Chicxulub site.

A recent study has added a new and surprising twist to the story (Bottke et al. 2007). Simulation models of the dynamics of the group of asteroids called the Baptistina family show that they could have originated with a fragmentation of a large asteroid $160 \mathrm{Myr}$ BP, perhaps due to a collision with another object. According to the model, the largest piece resulting from the fragmentation is the present-day asteroid 298-Baptistina, which still resides in the asteroid belt. Smaller pieces were scattered and many of them entered the inner Solar System. Bottke et al. (2007) speculate that the spectacular Tycho crater in the Moon is the result of the collision of one of this Baptistina objects 109 Myr BP. The Chicxulub crater could have been produced by another of the Baptistina objects that ended its $95 \mathrm{Myr}$ pilgrimage with an explosive encounter with Earth 65 Myr BP. If this is correct, Tycho and Chicxulub could be "sister craters" produced by an amazing sequence of improbable events.

\section{Under the sea: Cenozoic biogeography}

For more than $100 \mathrm{Myr}$, from the Cretaceous until the Pleistocene, numerous marine transgressions submerged the area of what is now the Yucatan peninsula under warm tropical waters. During this time limestone strata were formed with the remains of ancient coral reefs and seashells, including the uppermost Miocene-Pliocene (24-2 Myr BP) Carrillo Puerto Formation, a 15-m thick deposit of almost pure calcium carbonate that surrounds the shallow portions of present-day karst systems. Thus, the whole peninsula is basically a large limestone slab, submerged for millions of years, that is slowly emerging from south to north and where older deposits are located near the base.

When the Baptistina object collided with Earth at the end of the Cretaceous, what is now the Yucatan peninsula was a shallow coastal shelf at the southern extreme of North America. For millions of years, south of this tip there was a wide ocean separating North and South America, producing the independent evolution of early New World mammals in "splendid isolation" (Simpson 1980) until the Panamanian land bridge connected the two land masses ca 3.1-2.8 Myr BP (Fig. 3), triggering the great American biotic interchange (GABI), a major mixing of biotas from South and North America that shaped the high-level taxonomic composition of modern floras and faunas of the New World (Marshall et al. 1982, MacFadden 2006, Webb 2006).

Because the northern portion of the peninsula did not emerge until a few million years ago, the role of the Yucatan peninsula in the evolution of the terrestrial faunas of the Caribbean region during the Cenozoic was probably minor. Dispersal and vicariant theories have been proposed for the colonization of the Antilles and posterior in situ evolution (Dávalos 2004, Hedges 2006, Ricklefs and Bermingham 2008). Both types of hypotheses, however, call for a South American origin for the major vertebrate clades in the Antilles, with arrival and isolation times varying from theory to theory but pointing to around $35 \mathrm{Myr}$ ago (Iturralde-Vinent and MacPhee 1999). An alternative hypothesis for the origin of some vertebrate groups in the Antilles is the existence of a connection between the Yucatan peninsula and the islands at the beginning of the

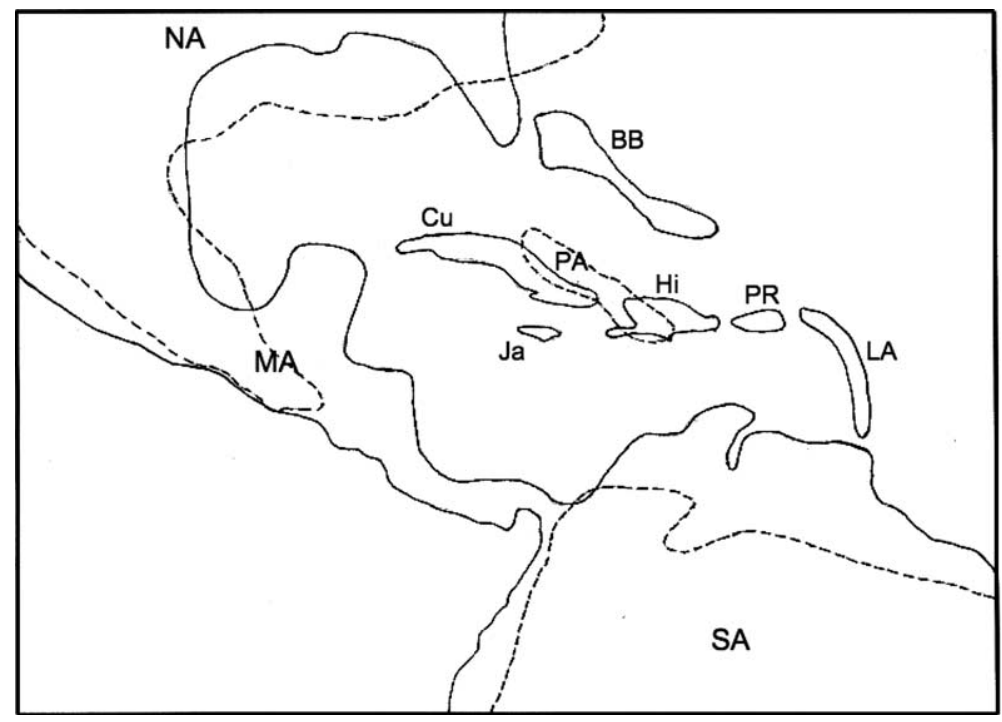

Figure 3. Emerged landmasses during the Middle Eocene (49-37 Myr BP), when North and South America were not connected (dotted line), and during the Pliocene (3.1-2.8 Myr BP) after the closure of the Isthmus of Panama (solid line), based on the model of Heinicke and collaborators (Fig. 4; Heinicke et al. 2007). Abbrevations: NA: North America, MA: Middle America, SA: South America, PA: Proto Antilles, Cu: Cuba, BB: Bahama Bank, Ja: Jamaica, Hi: Hispanola, PR: Puerto Rico, LA: Lesser Antilles. 
Cenozoic, with posterior isolation and vicariant evolution, a model that fits data for cichlid fish (Chakrabarty 2006). In any of the scenarios, biotic interchange between Yucatan and the Caribbean islands is thought to have been minimal throughout most of the Cenozoic, accounting for the present-day low similarity between the vertebrate faunas of these two areas (Vázquez-Miranda et al. 2007).

Nevertheless, for certain groups the Yucatan peninsula served as a bridge for dispersal between Central America and the Caribbean islands. For example, the present-day distribution of eleutherodactyline frogs is best explained by a model that includes several events of dispersal over water from and to South America and from Cuba to Yucatan at different times of the Cenozoic (Heinicke et al. 2007). Similarly, the evolution of mormoopid bats probably involved dispersal over water from the northern Neotropics to Central America and from there to the Antilles, most likely through the Yucatan peninsula (Dávalos 2006).

Interesting examples of evolution in the Yucatan fauna come from invertebrates inhabiting the fresh-water or anchihaline underground bodies of water. Shrimps of the genus Typhlatya are represented in the peninsula by three species occurring in fresh-water habitats. However, the divergence of this clade predates the origin of its present-day habitat, according to molecular data (Hunter et al. 2008). This result implies that the three species must have originated in marine habitats (the original medium of the genus) before the end of the Pliocene, when the freshwater habitats started to form. Subsequently, the three fully-formed species could have invaded the new habitat.

\section{The great American biotic interchange and the configuration of modern biotas}

The emergence of the Panama isthmus and the subsequent great American biotic interchange, peaking at approximately 2.8 Myr BP, marked the start of the processes that have configured the modern floras and faunas of the Yucatan peninsula and other Middle American regions (Fig. 1; MacFadden 2006). Before the closure of the Panama isthmus, all Mexican mammal faunas were completely North American in composition (Ferrusquia-Villafranca 2003, Webb 2006). Today, faunas of Middle America (Mexico plus Central America) are a rich and complex mixture of North and South American components, a clear evidence of the processes associated with the GABI.

North American mammalian faunas north of the Tropic of Cancer still consist mostly of elements of native families, with only a few South American components, such as opossums (Didelphidae), armadillo (Dasypodidae), a handful of phyllostomid and mormoopid bats. In contrast, faunas of tropical Mexico are rich assemblages that include both North and South American elements, some of which have evolved into idiosyncratic Mesoamerican endemics. Some families of North American origin (e.g. Tapiridae, Felidae, Sciuridae) are represented in the peninsula by species typically considered tropical (e.g. Baird's tapir Tapirus bairdii, jaguar Panthera onca and Deppe's squirrel Sciurus deppei). In addition, clades of South American origin are represented by primates (black howler monkey Alouatta pigra and Geoffroy's spider monkey Ateles geoffroyi), marsupials, bats, cingulata and pilosa (armadillo Dasypus novemcinctus and northern tamandua Tamandua mexicana) and hystricognath rodents (Central American agouti Dasyprocta punctata, and spotted paca Cuniculus paca).

Because of the geological history of the Yucatan peninsula, present-day faunas of the northern part of the peninsula are of recent origin, $<2.8 \mathrm{Myr}$. With very few exceptions, vertebrate faunas of northern Yucatan are subsets of the fauna of the base of the peninsula (the Peten and adjacent areas). Bats of the state of Yucatan, for example, represent a subset that cannot be distinguished from random samples of the fauna of the base of the peninsula, except that species with high dispersal capability are overrepresented in the northern fauna (Arita 1997). This suggests that faunas of the northern part of the peninsula originated simply by dispersal of species from the south. The big-eared climbing rat Ototylomys phyllotis for example, diverged and dispersed from South America toward Middle America coinciding in time with the GABI, and its present range includes the Yucatan peninsula (Gutiérrez-García and Vázquez-Domínguez unpubl.).

An example involving vicariant and dispersal events is the evolution of cantil pitvipers of the genus Agkistrodon (Parkinson et al. 2000). Phylogeographical studies showed that the genus Agkistrodon originally occupied relatively temperate habitats and evolved toward more tropical ones; the species Agkistrodon bilineatus, present now in the Yucatan peninsula, shows a historical initial divergence between populations from the eastern and western coasts in Mexico, with a posterior dispersal of one population to the Yucatan peninsula through subhumid corridors along northern Central America that diverged into a different subspecies, Agkistrodon bilineatus russeolus. These examples show that despite its apparent simplicity, the process of conformation of the Yucatan fauna can have many variations that depend on the idiosyncratic features of the different clades that are involved (Arita and VázquezDomínguez 2003).

As pointed out by Webb (2006), a major problem faced when studying the GABI is the lack of fossils of the right age at the right place. We have fossils either from the middle Miocene (well before the GABI) or from the Pleistocene (after the important processes had happened). In the Yucatan peninsula, fossils come from cave deposits of recent origin such as those from the Loltun cave in the southern part of the state. Sixty-eight animal species in ten orders, 25 families and 52 genera have been recorded as fossils in the cave, ranging in time between 30000 and 500 yr (Arroyo-Cabrales and Álvarez 2003 and references therein). Among the mammals found in the Loltun deposits are seven extinct species, including Pleistocene horses Equus conversidens, saber-toothed cats Smilodon fatalis, wolfs Canis dirus, mastodonts Cuvieronius sp. and camels Hemiuauchenia sp., together with the bat Desmodus draculae and the marsupial Marmosa lorenzoi (Arroyo-Cabrales and Álvarez 2003). These extinctions probably were caused by changes in climate or by the arrival of humans, although there is no direct evidence for either of these two factors. 


\section{The Holocene and Anthropocene}

Evidence of human occupation of the Yucatan peninsula in the Paleoindian period has been found in the Loltun cave and in Belize, where distinctive Clovis points have been recovered from deposits in Ladyville, that have been dated at 9000 to 7500 BC (Kelly 1993). Since then, the region has been populated by humans without interruption (Fig. 1). During the Classic period (250-900 AD), a large Maya city such as Tikal harboured populations of at least 50000 people, or perhaps even 100000 according to some estimates, and when the Spaniards arrived in 1519, the human population in the peninsula was probably as high as it is today (Fig. 1). Many people, thinking always of the great cities of the Classic period, visualize the Maya as a vanished human group, without realizing that they still number in the millions all over southern and eastern Mexico and in Central America.

Just as in other parts of the world, the cycles of development and decline of human groups in the Yucatan peninsula have been closely tied to climate conditions and the use of natural resources (Diamond 2005). There is mounting evidence of significant climate shifts in the peninsula associated with global conditions. For example, important sea level changes in the Yucatan peninsula 121 kyr ago, during the last interglacial period have been documented by analyzing fossil reefs of the peninsula (Blanchon et al. 2009). The study showed changes in sea level of up to $3 \mathrm{~m}$ in ecological time, perhaps as fast as in a few decades. Paleobotanical studies have documented dramatic changes in the vegetation cover of the peninsula. Only four thousand years ago, the Peten region was warmer and much dryer than it is today, and extensive savannahs existed in what is now covered with tropical rainforest. Forests began to dominate the landscape only about 2500 yr ago. In eastern Middle America, including sites in the Yucatan peninsula, the period with the densest tropical forests and deepest lakes coincides with the socalled Little Ice Age, 1350-1850 AD (Lozano-García et al. 2007).

In recent years, several studies have shown a strong correlation between changes in climate and the demise of the Classic Maya city-states. These studies are made possible not only by modern techniques that allow the reconstruction of past climates, but also by the precise calendar (the "long count") that the Classic Mayas used to record important events (Sharer and Traxler 2005). In every important city, steles were erected every $19 \mathrm{yr}$ and $265 \mathrm{~d}$ to mark the start of a new k'atun (period of 7200 days). In the year 790, at least 45 such monuments were built, but $100 \mathrm{yr}$ later only a dozen were produced, and on 15 January, 909, a sole stele was carved in the city of Tonina, in the highlands of Chiapas. This decline in the elaboration of monuments testifies the fall of each of the major Maya city-states of the Classic period: Palenque and Yaxchilan, in the Usumacinta river basin were abandoned first, at the beginning of the 9th century. Then, cities of present-day Belize and Guatemala followed suit and disintegrated by 860 . Finally, the mega-metropolis of the Peten, such as Tikal and Calakmul were deserted before 910. This sequence is important because it points to the fact that there was not a single collapse of the Classic Maya, but a series of events that took almost $100 \mathrm{yr}$ to develop.

In 1995 , a study of stable oxygen isotopes $\left(\delta^{18} \mathrm{O}\right)$ from sediments in a lake in Quintana Roo showed the existence of important dry spells coinciding with the end of the Classic period (Hodell et al. 1995), suggesting the idea that a "megadrought" could have triggered the fall of the cities. Years later, a study of the sediments of the Cariaco basin in South America, which allow the estimation of year by year rainfall patterns, demonstrated the existence not of a single event, but a series of extremely dry periods corresponding with the end of the Classic (Haug et al. 2003). Even more, the driest years (dated at 760,810,860 and 910 AD) coincided with the sequence of abandonment of the main Maya sites. This result points to severe drought as one of many possible causes of the collapse of Classic Maya citystates. New data on $\delta^{18} \mathrm{O}$ from the northern peninsula shows that the 15th century abandonment of some Postclassic sites, such as Mayapan, also coincides with a particularly harsh dry spell (Hodell et al. 2007), and recent evidence from several camps corroborates the megadrought theory (Pringle 2009). Of course, the so-called collapse of the Classic Mayas was a very long and complex process that involved other environmental, social, political and religious factors as well.

On 24 March, 1519, a new type of biogeographical process took place in the coast of Tabasco. Sixteen horses that arrived with the army of Hernán Cortés became the first animals introduced by Europeans into continental North America (Fig. 1). It is ironic that horses, which had evolved in North America only to become extinct there at the end of the Pleistocene (MacFadden 2006), gave a small band of a few hundred Spaniards the leverage to vanquish the powerful Aztec empire. After the Pleistocene extinctions, the native Middle American fauna lacked large mammals suitable for human use, so big domesticated animals were totally unknown to Mesoamerican Indians. Horses caused a tremendous impression on natives, becoming one of the most powerful weapons of the conquistadors. They were also the first in a long list of plants and animals introduced by Europeans that changed the structure and functioning of many ecosystems.

In the other direction, many native crops of the Yucatan peninsula were exported to the rest of the world. Two plants in particular played important roles in the configuration of the modern landscape of the Yucatan. The tapped sap of the sapodilla tree Manilkara zapota was used since pre-Hispanic times to produce a gum (the chicle) that could be chewed. From the 1870 s, when the chewing gum was introduced to the United States until the mid 1940s, the increasing demand for natural sapodilla gum was so big that it fostered the exploration of the forests of southern Yucatan in search of more trees to be exploited. These explorations contributed to the finding of many Maya ruins (Sharer and Traxler 2005), and catapulted the economic development of the whole area. After the invention of artificial substitutes for chicle in the 1940s, the demand for the natural product plummeted. Today, chicle is harvested only for specialized markets, mostly in Asia, that still prefer chewing gum based on natural products. 
The other plant that drove Yucatan's economy for a long time was henequen Agave fourcroydes. During the 19th century, demand for henequen or sisal fibers soared. At one point, up to $85 \%$ of the fiber used worldwide came from Yucatan, making the state one of the more affluent regions of Mexico by the 1880s. It was at this time that the huge haciendas in Yucatan's countryside flourished and the luxurious houses in Merida were built. Unfortunately for the environment, extensive plantations of the agave plant ruined hundreds of thousands of hectares, in an area where poor soil makes very difficult the cultivation of other crops. After World War I, the development of artificial fibres and the competition from countries that had smuggled henequen plants out of Yucatan and were producing their own fibre marked the end of the "green gold" boom in the peninsula.

The chicle tree and the henequen plant are only two examples of the complicated processes involving the use of natural resources in the Yucatan. Today's Yucatan environments are the result of millions of years of evolution, but also of the direct interaction with humans within the past 10000 yr. Even within Biosphere reserves, such as in the Calakmul area in the southern part of the peninsula, the landscape is a complex matrix of natural and humanmodified environments whose intermingling determines the dynamics of the rich biological diversity of the region (Vester et al. 2007).

\section{Present-day Yucatan}

\section{The geographic setting}

The ecological features and biogeography of the present-day Yucatan peninsula show the indelible mark of its 65 million yr history, as well as the evident effect of modern human activity. Politically, the peninsula comprises the entire territory of the states of Campeche, Yucatan and Quintana Roo. From a geomorphological point of view it also includes Belize, the Peten area of Guatemala and small portions of the Mexican states of Chiapas and Tabasco (Fig. 2). The limestone bedrock determines a terrain that is typical karst, dominated by a low and relatively flat plain of porous limestone with little soil. The highest point in the north is only $250 \mathrm{~m}$ (750 ft) in the Sierrita de Ticul. Surface water, in the form of small lakes and rivers, is confined to the southern part of the peninsula. In the north, all water reservoirs are underground, where there is a complex freshwater-saltwater interface (Escolero et al. 2007). The karst is also characterized by a large number of caves and cenotes (water-filled sinkholes) such as those at the rim of the Chicxulub crater (Perry et al. 1995, Schulte et al. 2010), that provide unique habitats for plants and animals (Arita 1996, MacSwiney et al. 2009, Vázquez-Domínguez et al. 2009).

Most of the region is warm and subhumid, but climate follows a pattern from dry in the north-northwest of the peninsula to very humid in the south-southeast. Temperature and rainfall vary from high mean annual temperatures $\left(26^{\circ} \mathrm{C}\right)$ and low annual rainfall $(500 \mathrm{~mm})$ in the northwest to lower temperatures and more abundant rainfall in the southeast (1400-2000 mm; Orellana et al. 2003).
Throughout most of the peninsula there is a very well defined rainy season from June to October, although winter rains are not uncommon in the south. Proximity to the Tropic of Cancer and the influence on the region of the Atlantic Bermuda-Azores anticyclone create both a high atmospheric activity and a strong north to south gradient of atmospheric pressure. This, together with the effect of trade winds and the influence of tropical perturbations allow the formation of hurricanes, a defining climatic feature of the whole Caribbean (Orellana et al. 2003). Because of its position, the Yucatan is hit harder and with higher frequency by hurricanes on the east coast, contributing to the east-to-west gradient of humidity that determines the physiognomy, phenology and structure of the vegetation of the peninsula. Hence, vegetation also follows a SE-NW gradient, from tropical rainforests in the Peten to tropical scrubland in the extreme NW portion of the peninsula. Extensive areas between these two extremes were originally covered with deciduous or semideciduous tropical forests (Carnevali et al. 2003).

\section{Diversity patterns and conservation}

The definition of biogeographic provinces is commonly based on the homogeneous distribution of the biota of a region, compared to that of adjacent areas. Early surveys of the Yucatan demonstrated a Neotropical affinity for its flora and fauna, evidenced by their composition. In particular, the Yucatan fauna is similar to that of other tropical dry zones, but it differs due to the presence of elements from the more humid areas of the south. This distinctiveness has prompted most scholars to consider the Yucatan peninsula a biotic province on its own, the Yucatan Peninsula Biotic Province (Fig. 2; Goldman and Moore 1945) or a region with two provinces, the Peten province in the south and the Yucatan province in the north. The former scheme has received much more support from recent analyses of geological and physiographic features, and of the distribution of plants, birds and mammals (Fa and Morales 1993, Morrone 2005).

Vascular plants in the Yucatan peninsula are very diverse, reaching 2600-3000 species. The six most common families represent ca $41 \%$ of the total flora of the region, including Fabaceae, Poaceae and Orchidaceae. However, species richness in the Yucatan is lower than that of comparable Neotropical regions of similar size. This fact results basically from the fairly recent origin of the peninsula, its relatively dry flat terrain, and its lack of superficial water, all of which preclude the presence of the many different microclimates and local heterogeneity that are typical of other Neotropical zones (Carnevali et al. 2003). Approximately $7 \%$ of the flora is endemic to the Yucatan peninsula, with some very distinctive, conspicuous and even dominant species, such as Acacia gaumeri (Fabaceae) and Myrmecophila christinae (Orchidaceae). Four genera are restricted to the province: Golmanella, Harleya, Plagiolophus and Asemnantha. Endemic species follow a particular distribution pattern, geographically divided in three parts: a northern "belt", with species such as Ipomea sororia (Convolvulaceae) and Mammilaria 
heyderi spp. gaumeri (Cactaceae); a southern zone with dominant species like Golmanella sarmentosa (Celastraceae), Epidendrum martinezii (Malvaceae) and Maytenus schippii (Orchidaceae); and a widespread component including species like Hampea trilobata (Malvaceae) or Acacia gaumeri (Carnevali et al. 2003).

Vertebrate assemblages in the Yucatan peninsula are rich in species, but less diverse than comparable regions in central and western Mexico (Lee 1980, Arita 1997, Zambrano et al. 2006). Nonetheless, high phylogenetic and taxonomic diversity characterise the region when compared with some areas of Central and tropical South America and Africa (Schipper et al. 2008). Few endemics, low richness of restricted species and higher representation of wide ranging species are also noticeable patterns (Arita and Rodriguez 2002, Arita and Vázquez-Domínguez 2003, Schipper et al. 2008). Finally, another defining feature of the peninsula is its low beta diversity when compared with other regions in Mexico (Arita and Rodriguez 2002). This is a consequence of the "everyone is everywhere" distribution pattern, shown most clearly by mammals, which in turn is the result of the peninsula's simple topography, lack of geographical barriers and low habitat heterogeneity.

Simpson's peninsula effect - a decrease in species diversity from the base to the tip of peninsulas - is clearly observed in the Yucatan peninsula (Simpson 1964). This is more evident for mammals, which vary in number from around 130 species in the base to 90 in the tip; for frogs, with 22 species in the base and nine in the north (Lee 1980), and for bats, with 85 species present in the south and only 31 in the north (Arita 1997). Likewise, the flora follows a conspicuous diversity pattern along the SE-NW rain gradient; the humid communities in the south having more species than their northern counterparts. An exception is seen for snakes and lizards, which are less diverse at the centre of the peninsula, and increase their richnesss towards the tip (Lee 1980).

Endemics include ca 20 reptiles, seven birds and 10 mammals. Richness of endemic amphibian and reptilian species follows an inverse "peninsula" pattern in which more endemic species occur in the north than in the south. In contrast, there is no distinctive gradient of richness of endemic mammals and birds, most of which are widely distributed within the peninsula (Arita and VázquezDomínguez 2003). Many endemic mammals, for instance, are distributed all over the peninsula and sometimes marginally to the piedmont of the highlands of Chiapas and Guatemala. Species showing this pattern include the Yucatan yellow bat Rhogeessa aeneus, the Yucatan squirrel Sciurus yucatanensis, Hatt's vesper rat Otonyctomys hatti, and the Yucatan black howler monkey Alouatta pigra.

All these particular biogeographic traits make the Yucatan an important place for conservation strategies despite the moderate absolute species richness of the region. For example, parts of the Yucatan have been identified as priority areas for the conservation of trees of the tropical deciduous forest (Cue-Bar et al. 2006) and carnivores (Valenzuela-Galván and Vázquez 2008). Likewise, the Yucatan peninsula is a hotspot for endemic helminth parasites of freshwater fishes (Aguilar-Aguilar et al. 2008).

\section{Conclusion}

Biogeography is by necessity a historical science, in the sense that present-day patterns of diversity and distribution of species cannot be understood without considering the geological and evolutionary history of the region. In today's Yucatan, patterns are the result of a wide variety of processes that have shaped the environments of the peninsula at different time scales, from 65 million yr to a few decades. Moreover, a full understanding of those processes is necessary to face the present and future conservation challenges posed by the complex intermixing of natural and social elements that characterize the peninsula. As Danish philosopher Soren Kierkegaard once wrote, life can only be understood backwards but it must be lived forwards.

\section{References}

Aguilar-Aguilar, R. et al. 2008. Richness and endemism of helminth parasites of freshwater fishes in Mexico. - Biol. J. Linn. Soc. 94: 435-444.

Alroy, J. et al. 2008. Phanerozoic trends in the global diversity of marine invertebrates. - Science 321: 97-100.

Alvarez, L. W. et al. 1980. Extraterrestrial cause for the Cretaceous-Tertiary extinction. Experimental results and theoretical interpretation. - Science 208: 1095-1108.

Arita, H. T. 1996. The conservation of cave-roosting bats in Yucatan, Mexico. - Biol. Conserv. 76: 177-185.

Arita, H. T. 1997. Species composition and morphological structure of the bat fauna of Yucatan, Mexico. - J. Anim. Ecol. 66: 83-97.

Arita, H. T. and Rodriguez, P. 2002. Geographic range, turnover rate and the scaling of species diversity. - Ecography 25: 541550.

Arita, H. T. and Vázquez-Domínguez, E. 2003. Fauna y la conformación de la provincia biótica yucateca: Biogeografía y macroecología. - In: Colunga-García Marín, P. and LarquéSaavedra, A. (eds), Naturaleza y sociedad en el área maya, pasado, presente y futuro. Academia Mexicana de Ciencias, CICY, pp. 60-80.

Arroyo-Cabrales, J. and Álvarez, T. 2003. A preliminary report of the late Quaternary mammal fauna from Lotún Cave, Yucatán, Mexico. - In: Schubert, B. W. et al. (eds), Ice Age cave faunas of North America. Indiana Univ. Press and Denver Museum of Nature and Science, pp. 262-272.

Blanchon, P. et al. 2009. Rapid sea-level rise and reef backstepping at the close of the last interglacial highstand. - Nature 458: 881-885.

Bottke, W. F. et al. 2007. An asteroid breakup $160 \mathrm{Myr}$ ago as the probable source of the K/T impactor. - Nature 449: 48-53.

Carnevali, G. et al. 2003. Flora y vegetación de la península de Yucatán. - In: Colunga-García Marín, P. and LarquéSaavedra, A. (eds), Naturaleza y sociedad en el área maya, pasado, presente y futuro. Academia Mexicana de Ciencias, CICY, pp. 53-68.

Chakrabarty, P. 2006. Systematics and historical biogeography of Greater Antillean Cichlidae. - Mol. Phylogenet. Evol. 39: 619-627.

Cue-Bar, E. M. et al. 2006. Identifying priority areas for conservation in Mexican tropical deciduous forest based on tree species. - Interciencia 31: 712-719.

Dávalos, L. M. 2004. Phylogeny and biogeography of Caribbean mammals. - Biol. J. Linn. Soc. 81: 373-394. 
Dávalos, L. M. 2006. The geography and diversification in the mormoopids (Chiroptera: Mormoopidae). - Biol. J. Linn. Soc. 88: 101-118.

Diamond, J. M. 2005. Collapse: how societies choose to fail or succeed. - Viking.

Escolero, O. et al. 2007. Dynamic of the freshwater-saltwater interface in the karstic aquifer under extraordinary recharge action: the Merida Yucatan case study. - Environ. Geol. 51: 719-723.

Fa, J. E. and Morales, L. E. 1993. Patterns of mammalian diversity in Mexico. - In: Ramamoorthy, R. et al. (eds), Biological diversity of Mexico: origins and distribution. Oxford Univ. Press, pp. 319-361.

Ferrusquia-Villafranca, I. 2003. Mexico's middle Miocene mammalian assemblages: an overview. - In: Flynn, L. (ed.), Vertebrate fossils and their context: contributions in honor of Richard H. Tedford. American Museum of Natural History, pp. 321-347.

Goldman, E. A. and Moore, R. T. 1945. The biotic provinces of Mexico. - J. Mammal. 26: 347-360.

Haug, G. H. et al. 2003. Climate and the collapse of Maya civilization. - Science 299: 1731-1735.

Hedges, S. B. 2006. Paleogeography of the Antilles and origin of West Indian terrestrial vertebrates. - Ann. Mo. Bot. Gard. 93: 231-244.

Heinicke, M. P. et al. 2007. Major Caribbean and Central American frog faunas originated by ancient oceanic dispersal. - Proc. Nat. Acad. Sci. USA 104: 10092-10097.

Hildebrand, A. R. et al. 1991. Chicxulub crater: a possible Cretaceous/Tertiary boundary impact crater on the Yucatán Peninsula, Mexico. - Geology 19: 867-871.

Hodell, D. A. et al. 1995. Possible role of climate in the collapse of Classic Maya civilization. - Nature 375: 391-394.

Hodell, D. A. et al. 2007. Climate and cultural history of the northeastern Yucatan Peninsula, Quintana Roo, Mexico. - Clim. Change 83: 215-240.

Hunter, R. L. et al. 2008. Phylogeny and historical biogeography of the cave-adapted shrimp genus Typhlatya (Atyidae) in the Caribbean Sea and western Atlantic. - J. Biogeogr. 35: 65-75.

Iturralde-Vinent, M. A. and MacPhee, R. D. E. 1999. Paleogeography of the Caribbean region: implications for Cenozoic biogeography. - Bull. Am. Mus. Nat. Hist. 238: 1-95.

Keller, G. et al. 2004. Chicxulub impact predates the K-T boundary mass extinction. - Proc. Nat. Acad. Sci. USA 101: 3753-3758.

Kelly, T. C. 1993. Preceramic projectile-point typology in Belize. - Ancient Mesoamerica 4: 205-227.

Kring, D. A. 2007. The Chicxulub impact event and its environmental consequences at the Cretaceous-Tertiary boundary. - Paleogeogr. Paleoclimatol. Paleoecol. 255: 4-21.

Lee, J. C. 1980. An ecogeographic analysis of the herpetofauna of the Yucatán Peninsula. - Univ. Kansas Misc. Publ. 67: 1-75.

Lozano-García, M. S. et al. 2007. Tracing the effects of the Little Ice Age in the tropical lowlands of eastern Mesoamerica. - Proc. Nat. Acad. Sci. USA 104: 16200-16203.

MacFadden, B. J. 2006. Extinct mammalian biodiversity of the ancient New World tropics. - Trends Ecol. Evol. 21: $157-165$.
MacSwiney, M. C. et al. 2009. Insectivorous bat activity at cenotes in the Yucatan Peninsula, Mexico. - Acta Chiropt. 11: 139-147.

Marshall, C. R. and Ward, P. D. 1996. Sudden and gradual molluscan extinctions in the latest Cretaceous of western European Tethys. - Science 274: 1360-1363.

Marshall, L. G. et al. 1982. Mammalian evolution and the Great American Interchange. - Science 215: 1351-1357.

Morrone, J. J. 2005. Hacia una síntesis biogeográfica de México. - Rev. Mex. Biodivers. 76: 207-252.

Orellana, R. et al. 2003. Presente, pasado y futuro de los climas de la península de Yucatán. - In: Colunga-García Marín, P. and Larqué-Saavedra, A. (eds), Naturaleza y sociedad en el área maya, pasado, presente y futuro. Academia Mexicana de Ciencias, CICY, pp. 37-52.

Parkinson, C. L. et al. 2000. Phylogeography of the pitviper clade Agkistrodon: historical ecology, species status, and conservation of cantils. - Mol. Ecol. 9: 411-420.

Perry, E. et al. 1995. Ring of cenotes (sinkholes), northwest Yucatan, Mexico - its hydrogeologic characteristics and possible association with the Chicxulub impact crater. - Geology 23: 17-20.

Pringle, H. 2009. A new look at the Mayas' end. - Science 324: 454-456.

Raup, D. M. and Sepkoski, J. J. 1982. Mass extinctions in the marine fossil record. - Science 215: 1501-1503.

Ricklefs, R. E. and Bermingham, E. 2008. The West Indies as a laboratory of biogeography and evolution. - Phil. Trans. R. Soc. B 363: 2393-2413.

Schipper, J. et al. 2008. The status of the World's land and marine mammals: diversity, threat, and knowledge. - Science 322: 225-230.

Schulte, P. et al. 2010. The Chicxulub asteroid impact and mass extinction at the Cretaceous-Paleogene Boundary. - Science 327: 1214-1218.

Sharer, R. and Traxler, L. 2005. The ancient Maya, 6th ed. - Stanford Univ. Press.

Simpson, G. G. 1964. Species density of North American recent mammals. - Syst. Zool. 12: 57-73.

Simpson, G. G. 1980. Splendid isolation: the curious history of South American mammals. - Yale Univ. Press.

Valenzuela-Galván, D. and Vázquez, L. B. 2008. Prioritizing areas for conservation of Mexican carnivores considering natural protected areas and human population density. - Anim. Conserv. 11: 215-223.

Vázquez-Domínguez, E. et al. 2009. Contrasting genetic structure in two codistributed freshwater fish species inhabiting highly seasonal systems. - Rev. Mex. Biodivers. 80: 181-192.

Vázquez-Miranda, H. et al. 2007. Biogeographical patterns of the avifaunas of the Caribbean Basin Islands: a parsimony perspective. - Cladistics 23: 180-200.

Vester, H. F. M. et al. 2007. Land change in the southern Yucatan and Calakmul Biosphere Reserve: effects on habitat and biodiversity. - Ecol. Appl. 17: 989-1003.

Webb, S. D. 2006. The great American biotic interchange: patterns and processes. - Ann. Mo. Bot. Gard 93: 245-257.

Zambrano, L. et al. 2006. Fish community structure in freshwater karstic wetlands of the Yucatan peninsula, Mexico. - Ichthyol. Explor. Freshwaters 17: 193-206. 